\title{
Diagenesis and Its Effect on Reservoir Quality of Silurian Sandstones, Tabei Area, Tarim Basin, China
}

\author{
Zhang Jinliang, Jia Ying and Du Guilin \\ (School of Geosciences, Ocean University of China, Qingdao, Shandong 266003, China)
}

\begin{abstract}
The diagenetic processes of the Tabei sandstones in the Tarim Basin include compaction, cementation (quartz overgrowths, calcite, clay minerals and a minor amount of pyrite), and dissolution of the feldspar and calcite cement. Porosity was reduced by compaction from an assumed original $40 \%$ to about $22.1 \%$. Cementation reduced porosity to $26.6 \%$. The Tabei sandstones lost a little more porosity by compaction than by cementation. Quartz cementation, especially syntaxial quartz overgrowth, is a major cause of porosity-loss in many reservoirs in moderately to deeply buried sandstone. Calcite cementation played a key role in the porosity evolution of sandstones. At the early stage of burial, the early calcite cement occupied most of the pore spaces resulting in significant porosity. On the other hand, some primary porosity has been preserved due to incomplete filling or the presence of scattered patches of calcite cement. In addition to calcite, several clay minerals, including illite and chlorite occurred as pore-filling and pore-lining cements. The pore-lining chlorite may have helped in retaining the porosity by preventing the precipitation of syntaxial quartz overgrowths. Illite, which largely occurred as hair-like rims around the grains and bridges on the pore throats, caused a substantial deterioration of penetrability of the reservoir. Calcite cement dissolution was extensive and contributed significantly to the development of secondary porosity.
\end{abstract}

Key words: Tarim Basin, diagenesis, secondary pore, reservoir quality

\section{Introduction}

The Tarim basin, surrounded by Tianshan Mountains and Kunlun Mountains, is located in the southern part of Xinjiang Uygur autonomous Region and is the largest sedimentary basin in China, covering $56 \times 10^{4} \mathrm{~km}^{2}$. As an important basin, Tarim Basin experienced several periods of tectonic movement and depositional cycles, with source rock sections developed in different strata. During the Silurian period, the stable central basin was the Tarim plate, the basin was an active continental margin and the southern basin was the Aerjin marginal uplift and the Kunlun foreland thrust faulted zone. The Tabei area lies in the north of the Tarim basin. The Qunke rift zone and Akesu lie in its east and west, respectively. To the north, it is Erbatai rift and to the south, it is transitional to the Tazhong area.

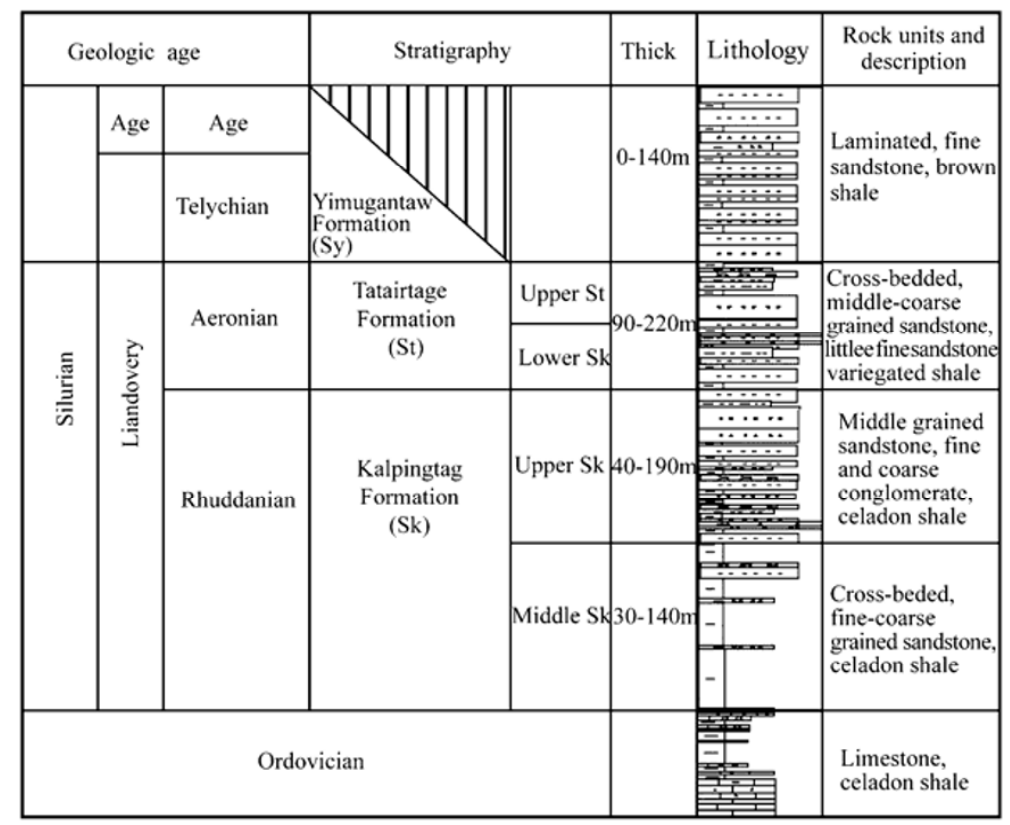

Fig. 1 Stratigraphic succession of Silurian in the Tabei Area 
In the Tarim basin, the Silurian in Tabei area is belonged to Palaeozoic Era, which is divided into: early, middle and late Silurian, corresponding to Yimugantaw (Sy) Formation, Tatairtage Formation (St) and Kalpingtag Formation (Sk) respectively. The St Formation and Sk Formation can be further subdivided into two sub-formations respectively, in the following as, upper St Formation, lower St Formation, upper Sk Formation and middle Sk Formation. The absence of the Sk Formation is observed in most of the Tabei area, partially St Formation in some place of the Tabei area. The Sy Formation overlies the St Formation, which consists mostly of middle-coarse grained sandstone, little fine sandstone deposited in Lower Braided Plain environment. The Sk Formation is about $70-330 \mathrm{~m}$ thick and comprises fine-coarse sandstone and coarse conglomerate. Sedimentary structure, such as cross-bedding is observed (Fig. 1).

The Tabei area in the Silurian was controlled by a braided delta system. This system was subdivided into three subfacies: upper braided deltaic plain, lower braided deltaic plain and subaqueous braided delta. Furthermore, lower braided deltaic plain includes five types of microfacies, including braided deltaic channel, distributary-mouth bar, distal bar, sheet sand and natural barrier (Fig. 2).

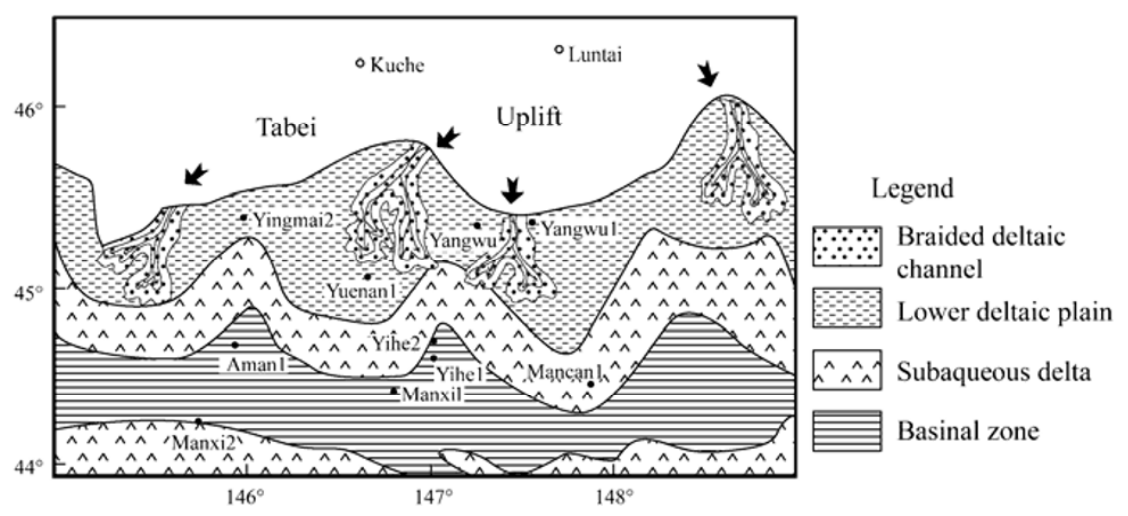

Fig. 2 Main wells and sedimentary microfacies in the Tabei area, Tarim Basin

This study is based on the samples of Silurian reservoir obtained from 7 wells (Th1, Ym2, Yw2, Sl1, Cao1, H1 and Yn1) in the Tabei area, northern Tarim basin. In this study, scanning electron microscopy, $\mathrm{X}$-ray diffraction, cathodoluminescence and electron microprobe analysis were used and a large amount of thin sections (ordinary thin section, cast thin section and cathodoluminescence thin section) were available to study the diagenesis and types of porosity. Based on the data analysis, the lithologic characteristics of sandstones, diagenetic minerals, evolutionary stages of diagenesis, reservoir quality, the genesis and distribution of porosity were fully discussed, in order to indicate the evolution model of sandstones reservoir in the Tabei area, Tarim basin.

\section{Lithologic characteristics}

A total of 102 thin sections representing 7 wells were investigated under a polarizing microscope for textural and mineralogical attributes. The middle Sk sandstones are litharenite and sublitharenite, containing an average of $73 \%$ quartz, $25 \%$ lithic fragment and 2\% feldspar. The upper Sk sandstones are litharenite, sublitharenite and rarely quartz arenite (well H1), with the framework consisting predominantly of quartz (av. 55\%), lithic fragment (av. 38\%) and feldspar (av. 7\%) (Fig. 3).

Thin-section petrography shows that almost all of the Silurian sandstones are very-fine to fine $(0.125-0.25 \mathrm{~mm})$. The shapes of the grains vary from subangular to subrounded. The major type of grain contact is point-line, and the main type of cementation is pore. The types of sorting change with different

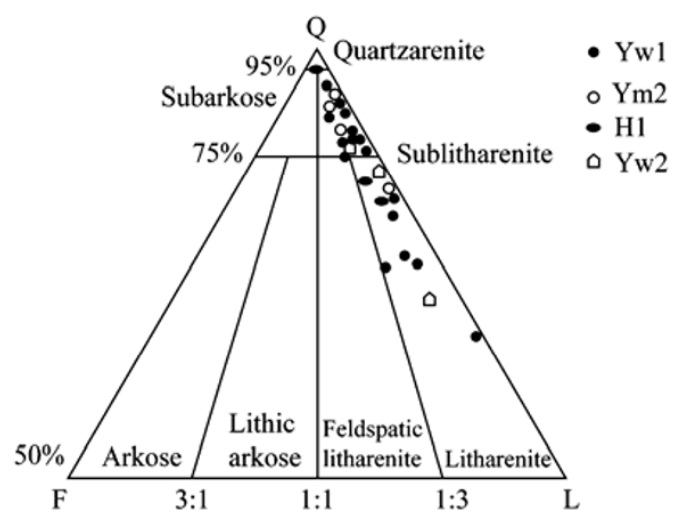




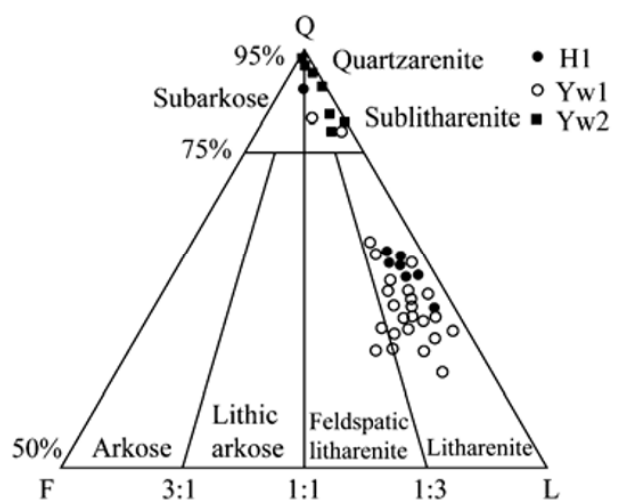

Fig. 3 Types of sandstone from the Silurian reservoir, Tarim Basin in middle Sk (left) and upper Sk (right) (After Folk, 1968)

formations: the middle Sk, the lower and upper St sandstones are well sorted, but the upper Sk sandstones are medium to well sorted.

\section{Diagenesis of sandstone and its effect on reservoir quality}

\subsection{Compaction}

Compaction and cementation of sediments played a major role in reducing porosity (Fisher, et al., 1999). Conspicuous evidence of mechanical compaction includes the fracturing of quartz and feldspar grains (commonly healed by authigenic quartz) and by the deformation of ductile grains. Chemical compaction occurred by pressure dissolution both along intergranular contacts and stylolites. In this study, the closely packed sandstones shows three types of grain contacts in Tabei reservoirs, which include point-, long (line contact)- and concavo-convex contacts.

Compaction is limited in sandstones cemented by abundant eogenetic silica or carbonate cementation. Locally, in sandstones cemented by microquartz rims, pressure dissolution is limited to intergranular sutured and concave-convex contacts with rare, low-amplitude $(0.1 \mathrm{~mm})$. The sandstones show the effects of both mechanical and chemical compaction by the loss of initial porosity, ductile and brittle deformation of grains. Mechanical compaction is the dominant process, whereas chemical compaction is scarcely found, resulting in a major loss of primary porosity.

When assessing the diagenetic modification of primary porosity, it is useful to separate the effects of compaction from the effects of cementation. The relative importance of the two processes can be visualized by the use of Ehrenberg's (1989) diagram (Fig. 4). Compaction is limited in sandstone cemented by abundant silica or carbonate cementation. Cementation increased the framework strength of the sediments and preserved primary porosity from compaction reduction.

All the time of deposition, clean well sorted sandstones have an initial porosity value. This value was assumed for the studied sandstones. After deposition, that porosity was reduced by compaction and cementation. The total amount of porosity lost by compaction (COPL) of sandstones can be expressed by the following equation (Ehrenberg, 1989).

$$
C O P L=O P-\frac{(100 \times I G V)-(O P \times I G V)}{100-I G V}
$$

Where $\mathrm{OP}=$ the original porosity $(40 \%)$ and $\mathrm{IGV}=$ the intergranular volume (intergranular porosity + pore filling cement). The amount of porosity lost by cementation (CEPL) of sandstones can be expressed by the following equation:

$$
C E P L=(O P-C O P L) \times \frac{C E M}{I G V}
$$

The results of equations show that more porosity was lost by compaction than by cementation. The average is $17.9 \%$ (up to $28 \%$ ) porosity loss by compaction, average $13.4 \%$ (up to 29 ) porosity loss by cementation.

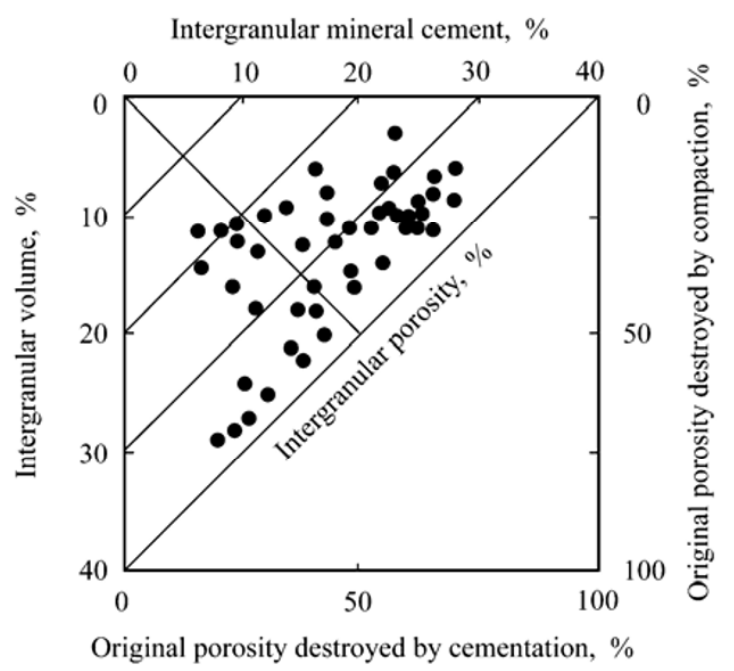

Fig. 4 Diagram showing the relative importance of compaction versus cementation to porosity development in the sandstones (After Ehrenberg, 1989)

\subsection{Cementation}

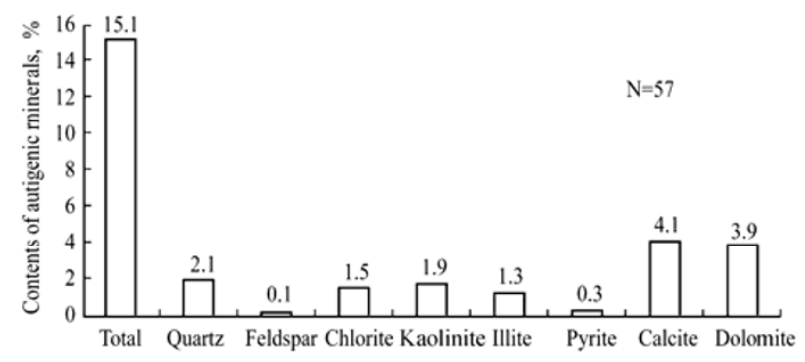

Fig. 5 Types of authigenic mineral illustrated by histograms in Silurian reservoirs of Tabei area 
Silurian diagenetic minerals consist of quartz, calcite, dolomite, illite, kaolinite, chlorite, pyrite, feldspar etc. The occurrence of these minerals in the sandstone sequence is described below (Fig. 5).

\subsubsection{Quartz}

Siliceous cements are developed commonly in the studied region. The precipitation of quartz overgrowths and outgrowths occurred after effective burial and compaction. This is indicated by (1) the intergrowth of quartz with fibrous illite; (2) the relatively small intergranular volume and quartz overgrowths volume (Fig. 6A) (3) the partial replacement of post-compactional, poikilotopic anhydrite by quartz. Silica cement was primary exhibited as secondary enlargement quartz, and could develop into mosaic contacts of quartz grains. Siliceous cement does not glow under a cathodoluminescence microscope and it has great influence on porosity loss.

The quartz overgrowths accounts for over 1 to $8 \%$ in the studied region, even accounts for $12 \%$ in a few samples. In general, the degree of quartz secondary enlargement is divided into 5 degrees, according to the characteristics of quartz of the Tabei area, the quartz secondary enlargement is of II-III degree.

According to electron probe analysis, the components of overgrown quartz are: $\mathrm{SiO}_{2} 98.6 \%$ $-99.32 \%, \mathrm{Na}_{2} \mathrm{O} 0.14 \%-0.99 \%, \mathrm{FeO} 0.01 \%-0.03 \%$, $\mathrm{MgO} 0.03 \%-0.2 \%, \mathrm{CaO} 0.19 \%-0.37 \%$, MnO 0.51\%.

From the silica sources commonly considered for quartz cementation, three could be invoked as potential sources for the precipitation of quartz overgrowths in the Tabei sandstones: (1) the pressure dissolution of detrital quartz along intergranular contacts and stylolites; (2) the dissolution or alteration of detrital silicates, mainly of feldspars; (3) the illitisation of detrital and authigenic smectite or kaolinite. Pressure dissolution was an important source of silica for quartz overgrowth cementation in the Tabei sandstones, as indicated by the common occurrence of sutured intergranular contacts and discrete stylolites.

The illitisation of eogenetic smectite and kaolinite may have partially supplied silica to mesogenetic quartz precipitation (Madhavaraju, et al., 2002). Assuming $\mathrm{K}$-feldspar as the most likely source of potassium, the transformation of smectite in illite can be described as follows:

$$
\underset{\text { (K-feldspar) }}{2 \mathrm{~K}\left[\mathrm{AlSi}_{3} \mathrm{O}_{8}\right]+2 \mathrm{~K}_{0.3} \mathrm{Al}_{1.9} \mathrm{Si}_{4} \mathrm{O}_{10}(\mathrm{OH})_{2} \rightarrow 2 \mathrm{~K}_{0.8} \mathrm{Al}_{1.9}\left(\mathrm{Al}_{0.5} \mathrm{Si}_{3.5}\right) \mathrm{O}_{10}(\mathrm{OH})_{2}+4 \mathrm{SiO}_{2}} \text { (illite) }
$$

Furthermore, illitisation of kaolinite may also supply silica for mesogenetic quartz precipitation:

$$
2 \mathrm{~K}\left[\mathrm{AlSi}_{3} \mathrm{O}_{8}\right]+\mathrm{Al}\left[\mathrm{SiO}_{5}\right](\mathrm{OH})_{4} \rightarrow 2 \mathrm{KAl}_{3} \mathrm{Si}_{3} \mathrm{O}_{10}(\mathrm{OH})_{2}+4 \mathrm{SiO}_{2}+\mathrm{H}_{2} \mathrm{O}
$$

$$
\text { (K-feldspar) (kaolinite) (illite) }
$$

The above equation states that one mole each of $\mathrm{K}$-feldspar and kaolinite will react to precipitate one mole of illite in sandstones that is heated to temperatures higher than $120-140 \quad{ }^{\circ} \mathrm{C}$. Therefore, the K-feldspar/kaolinite ratio developed at shallow depths controls whether there will be excess K-feldspar or kaolinite after illitisation in the deeply buried sandstones.

As determined by cast thin section observations, cathodoluminescence characteristics and XRD analysis, mass balance calculations show that enough silica was released during the dissolution of feldspar to provide the amount of quartz cement in the Tabei sandstones.

\subsubsection{Carbonate cements}

Carbonates are important cements in the studied region, and consist of calcite, Fe-dolomite, ankerite and siderite.

Calcite cement generally is the most significant authigenic constituent in the Tabei sandstone. Calcite cements are ubiquitous in the sandstones, with their proportions varying from nearly 2 to as much as $11 \%$. Calcite occurs as blocky to poikilotopic, intergranular cement (Fig. 6B) and as grain replacing cement. On (quartz)

average about one-third of the calcite is gain replacing. Calcite replaces both quartz and feldspar grains, as well as their overgrowth and rock fragments (Carvalho, et al., 1995).

Calcite has a wide textural and compositional variety including (1) microcrystalline pore-filling $(1-6 \mu \mathrm{m})$ calcite cement lenses with contents of carbonate bioclast, oncolithes and intraclasts, (2) isopachous calcite rims 20-30 $\mu \mathrm{m}$ thick, which occur around bioclasts and oncolithes with microcrystalline cement, (3) blocky and prismatic calcite crystals which fill moldic pores generated by the selective dissolution of bioclasts, (4) fine pseudospar mosaic calcite $(10-100 \mu \mathrm{m})$ which surrounds zones cemented by microcrystalline calcite, (5) coarse non-ferroan mosaic calcite $(\geq 100 \mu \mathrm{m})$ (6) coarse ferroan mosaic to poikilotopic calcite $(100-200 \mu \mathrm{m})$ which systematically covers and thus post-dates the coarse non-ferroan calcite.

Calcite cementation plays a key role in the porosity evolution of sandstones (Alaa, et al., 2000). At the early stage of burial, the early calcite cement occupied most of the pore spaces resulting in significant porosity. On 
the other hand, some primary porosity has been preserved due to incomplete filling or the presence of scattered patches of calcite cement.

Dolomite occurs as poikilotopic crystals and less frequently, as mosaics of rhombic crystal (Khalid, et al., 2004). A high Fe content of the dolomite is indicated by
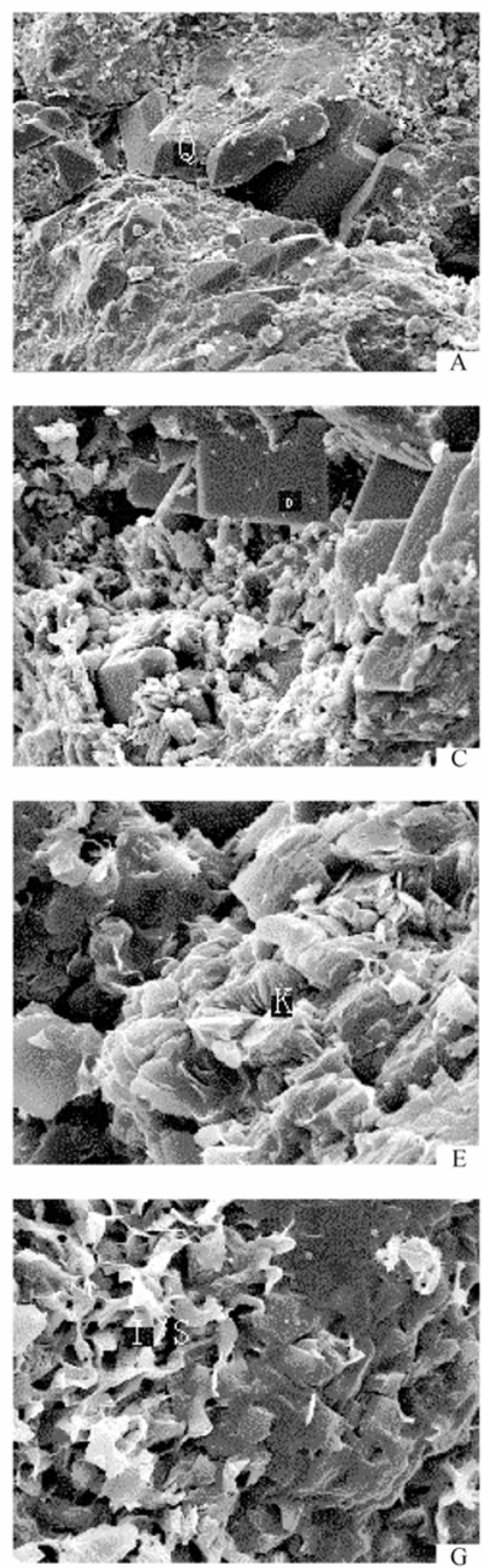

its blue staining with potassium ferricyanide and was confirmed by EDX analysis. Fe-dolomite cement is present in most of samples. Fe-dolomite shows a blocky to poikilotopic habit $(0.1-10 \mathrm{~mm})$ (Fig. 6C), occurring as intergranular, locally replacive and displacive cement in Tabei sandstones.
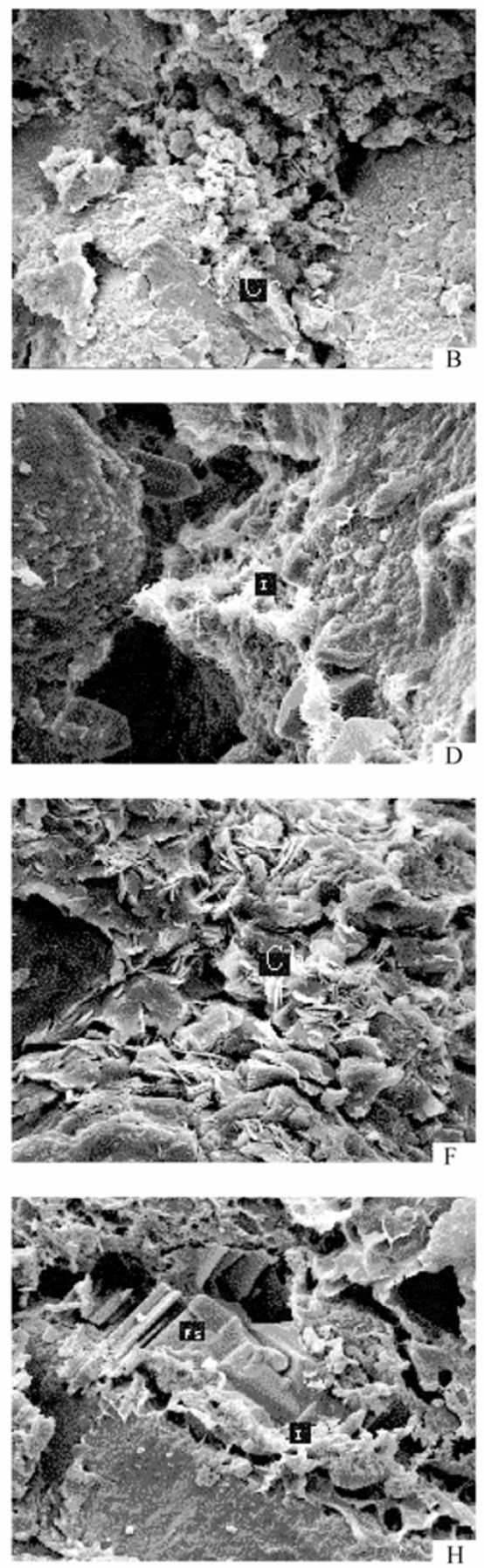

Fig. 6 SEM photomicrographs shows authigenic minerals

(A) Development of quartz overgrowths, Well Ym2(depth 5020.7m);

(C) Fe-dolomite infills the primary pores, Well H1 (depth $6157.77 \mathrm{~m}$ );

(E) Booklet kaolinite infills pore spaces, Well H1 (depth 6317.83m);

(G) Mixed-layer illite-smectite infilling pore spaces, Well Cao 1(depth $5025.87 \mathrm{~m}$ );
(B) Calcite fills pore spaces, Well Yw2(depth $5210.6 \mathrm{~m}$ );

(D) Fibrous illite fills pore spaces, Well H1 (depth $6227.3 \mathrm{~m}$ );

(F) Rosette chlorite infilling the pore spaces, Well Caol (depth $5028.73 \mathrm{~m}$ );

(H) Feldspar overgrows, Well Yw1 (depth 5220.1m) 


\subsubsection{Clay minerals}

Clay minerals identified in the Silurian of Tabei sandstones include illite, kaolinite, chlorite, mixed-layer illite-smectite etc. As determined by XRD analysis of 102 samples in the Tabei area, illite is the most common clay mineral, being present in almost all analyzed samples. Kaolinite authigenes are abundant in some samples, and mixed-layer illite-smectite also appears throughout some of the sections. The presence of chlorite is restricted. With the influence of diagenesis, the clay minerals change with increasing burial depth: Mixed-layer illite-smectite and burial depth better correlate at first and negative correlation appears later. Chlorite and illite have a better correlation with burial depth. Kaolinite is not correlated with burial depth obviously (Fig. 7).

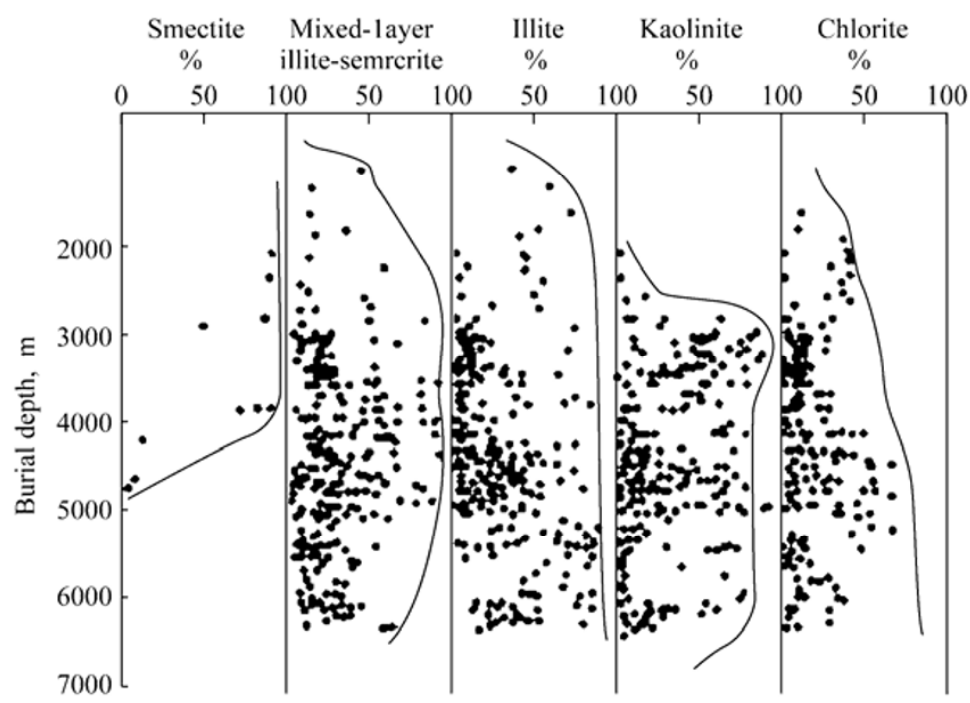

Fig. 7 Clay mineralogy of sandstone samples determined by X-ray diffraction as a function of depth

\section{(1) Illite}

Illite is a common constituent of the Silurian sandstones in the study area. It is found mostly within the matrix and partly in pore spaces. Illite was formed both by direct neoformation in the pores and by replacement of kaolinite and smectite precursors (Aynur and Ali, 2005). Illite forms up to about $2 \%$ of the rocks, occupying up to $25 \%$ (up to $40 \%$ ) of the clay minerals. Illite is represented by three different texture types: (1) hair-like, radially disposed crystals (2) fibrous (3) membranous, which occur as pore-filling and pore-lining cement. Pore-lining, hairy illite has been reported.

Authigenic hair-like illite occurs in some samples, although its content rarely exceeds $1.5 \%$ of the rock volume. Illite grows into pore space engulfing dolomite and quartz. Secondary pores, formed due to the dissolution of feldspar grains, are usually filled with pore-lining cement consisting of authigenic illite.

A large amount of late-diagenetic fibrous illite occurs throughout the entire Silurian succession (Fig. 6D). It forms hair- or thread-like crystals that have replaced or intergrown with previous authigenic or detrital clay. It also forms pore-bridges overlying, and locally partially enclosed within quartz cements. Illite preferentially replaces or intergrows with vermicular kaolinite (Wescott, et al., 1983). Less commonly, authigenic illite occurs with honeycomb or spiny morphology. The honeycomb morphology of illite suggests that the authigenic illite contains some smectite interlayers. Unsilicified pseudomatrix was replaced by illite. Illite replacement of kaolinite is pseudomorphic, preserving the vermicular and booklet habits of the kaolinite aggregates. Such illitised kaolinite occurs adjacent to secondary pores after feldspar dissolution. Illite replaces the feldspar grains along cleavage boundaries and twinning planes.

EMP analysis of illite composition: $\mathrm{SiO}_{2} 52-59 \%$, $\mathrm{Al}_{2} \mathrm{O}_{3} 23-24 \%, \mathrm{~K}_{2} \mathrm{O} 8-9 \%$, FeO 2-5\%, $\mathrm{MgO} 2-3 \%$, $\mathrm{CaO} 0-0.27 \%, \mathrm{TiO}_{2} 0-0.24 \%$.

(2) Kaolinite

Authigenic kaolinite occurs in nearly all the studied sandstones. Total kaolinite clay contents average $26 \%$ (up to $79 \%$ ) of clay minerals. This mineral occurs in four micromorphological varieties. The first is represented by small columnar, vermicular aggregates of the same size, forming pore-filling cements in the empty pore space of sandstones (Fig. 6E). The second variety of kaolinite is represented by individual plates. They are thick, pseudohexagonal, up to $50 \mathrm{~mm}$ in size 
with distinct steps of growth. The third variety is represented by multiple aggregates. Some of them are formed due to alteration of feldspar grains. The last, large columnar, are not related directly to silicate gains forming the framework of rocks, but they are similar in size.

Authigenic kaolinite occurs infilling the pore spaces in two growth forms: as well developed euhedral pseudohexagonal plates forming booklets and aggregates and as thin, skeletal subhedral plates commonly forming vermicules. Sandstones containing grain-coating kaolinite are relatively friable, white to reddish, typically contain root traces, and have low macroporosity and very low permeability (Hiatt, et al., 2003). Pore-filling kaolinite is a common feature in which pore spaces are usually plugged with authigenic kaolinite with no apparent preferred orientation. Pore-filling kaolinite occurs as stacked sequences of pseudohexagonal plates, growing between the detrital grains and exhibiting bridges. Replacement kaolinite generally generates as a replacement product of feldspars. Kaolinites in these sandstones are authigenic, and include both cements and replacement of silicate framework grains.

(3) Chlorite

Chlorite was observed in most of the samples of the Silurian sandstones in the Tabei area. In the Tabei sandstones, chlorite occurs both as a pore-filling mineral (Fig. 6F) and a replacement mineral of detrital grains, such as feldspar, rock fragments and partly quartz overgrowths and calcite cement. Chlorite occupies $3 \%$ of the rock volume. Pore-filling chlorites appear as rosettes or crystal aggregates within the pores (Pimentel, 2002). Chlorite also grows tangentially to the surface of detrital grains, forming 'rosette' type structures. Well-developed pseudohexagonal crystals cover or are partially engulfed by quartz over growths.

Under SEM, the chlorite coatings were seen as delicate plate crystals standing perpendicular to the grain surfaces. If quartz grains were coated by chlorite completely, little or no quartz overgrowths would be shown (Schmid, et al., 2004). Hence, some primary porosity has been preserved due to chlorite cement. In the Tabei sandstones, the development of chlorite rims around quartz grains appears to have helped the preservation of porosity by preventing the development of quartz overgrowths. XRD data of these sandstones revealed that clay minerals average $14 \%$ (trace to $27 \%$ ), in which chlorite comprises $30 \%$ (trace to $71 \%$ ).

Based on the analysis of EMP, the components of chlorite are: $\mathrm{FeO} 23.10-28.80 \%, \mathrm{Al}_{2} \mathrm{O}_{3} \quad 13.70-20.80 \%$, $\mathrm{MgO} 5.4-16 \%, \mathrm{Na}_{2} \mathrm{O} 0-0.51 \%, \mathrm{TiO}_{2} 0-4.10 \%, \mathrm{SiO}_{2}$
$28.60-38.40 \%, \mathrm{~K}_{2} \mathrm{O} 0-6.10 \%, \mathrm{CaO} 0.04-0.40 \%$.

(4) Mixed-layer illite-smectite

Mixed-layer illite-smectite is widespread in the studied region (Fig. 6G). X-ray diffraction data of these sandstones revealed that mixed-layer illite-smectite occupied $22 \%$ (max. $15 \%$, min. $30 \%$ ) of the clay minerals. As determined by XRD analysis, mixed-layer illite-smectite clays were well-ordered, and they were formed by the transformation of detrital smectite from bioturbation matrix or pseudomatrix formed by the compaction of mud intraclasts. On the process of diagenesis, smectite turns into mixed-layer illite-smectite with increasing burial depth (Zhang, 2004).

(5) Feldspar

Feldspar cement is not common in the Tabei sandstones but does occur as syntaxial overgrowths on some feldspar grains. Chemical conditions favoring feldspar overgrowths include a supply of sodium, potassium and silica (Fig. 6H) (Haszeldine and Macaulay, 2000). Generally, several dissolution textures can be identified, including: (1) grain-contact dissolution, (2) replacement of feldspar by carbonates, (3) dissolution of K-feldspar overgrowths. Sutured intergranular quartz and feldspar contacts provide evidence of grain-contact quartz and feldspar dissolution.

(6) Pyrite

Diagenetic pyrite framboids are always found in the pore spaces of sandstones. The content of pyrite is commonly low, but in a few samples, it is high. Pyrite is locally abundant along the contacts between sandstone beds and underlying mudstone, where it occurs as nodules of up to $1 \mathrm{~cm}$ in size. Based on the analysis of the data from electron microprobe, the abundance of iron in pyrite is $46.63 \%-47.61 \%$, sulfur is $51.99 \%-52.97 \%$. Generally speaking, the composition changes with the environment. The value of $\mathrm{S} / \mathrm{F}$ indicates the degree of deoxidization of some region. Based on the value of $\mathrm{S} / \mathrm{F}$ of the Tabei sandstones, pyrite was formed in a deoxidized environment.

\subsubsection{Sulfate cement}

Anhydrite and barite cements are also not common in the studied region. Anhydrite typically occurs as up to $100 \mu \mathrm{m}$ poikilotopic rhombs infilling pores but also as vein-filling cement (Zhang and Shen, 1990). The sulfate necessary for anhydrite and barite formation was likely sourced by the dissolution of anhydrite, which is abundant in the evaporate sequence overlying the Silurian. Because anhydrite and barite are probably late diagenetic minerals, the sulfate-precipitating waters could have been relatively similar to the present-day formation brines. Although the origin of these brines is probably complex, their extremely 
high salinity suggests that the dissolution of evaporates might have played a role in their formation.

The main controls on reservoir quality in the Tabei sandstones are carbonate cement, including calcite, dolomite, Fe-dolomite and siderite and total clay minerals. A substantial part of the calcite cement recognized in Tabei sandstone is distributed uniformly throughout the sandstone. Based on the nature and distribution of different types of cements, especially calcite, it plays a key role in porosity-loss in Tabei reservoirs. Calcite cements which were formed early in diagenesis were subjected to dissolution, and followed by precipitation of new calcite cements in later diagenesis (Marfil, et al., 1996). The early calcite cementation played a constructive role in porosity preservation because it could prevent significant early mechanical compaction and its dissolution in later diagenesis could generate secondary porosity. However, if early cementation was abundant and almost completely occluded primary porosity, later dissolution was compensated by re-precipitation of calcite and no new porosity was created. In contrast, if early calcite cementation was minor but sufficient to strengthen the framework against compaction, its role for porosity preservation is optimized. New porosity was generated if the dissolution of this early calcite cement was not compensated by new cement formation. In most samples, however, calcite cements only partly fill porosity, leaving much open space, part of which could have resulted from later dissolution of the calcite cements.

Including the carbonate cements in Tabei sandstones, the content of carbonate cements and reservoir quality could be expressed by negative correlation (Fig. 8).
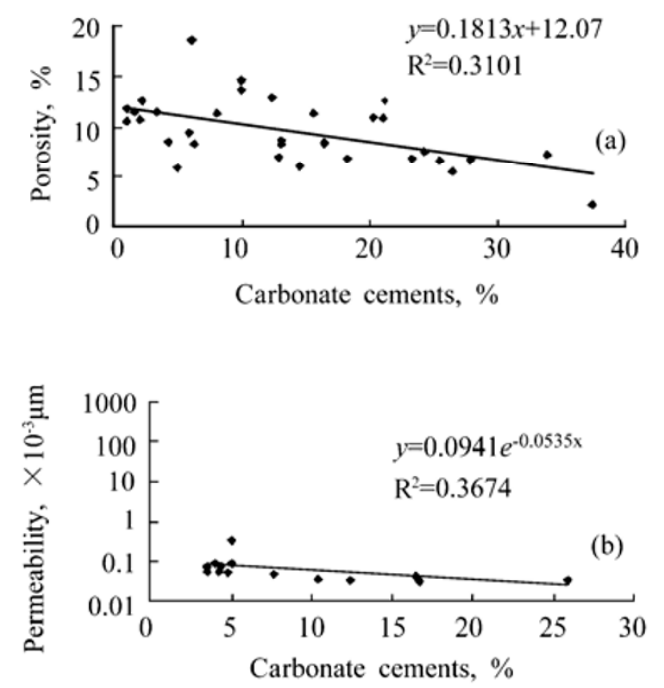

Fig. 8 Plots of porosity vs. carbonate and permeability vs. carbonate: (a) Porosity vs. carbonate cement measured in thin section; (b) Permeability vs. carbonate cement
Quartz overgrowth is an important mechanism for reducing the quality of many deep reservoirs (Worden and Morad, 2000). Quartz cementation, more specifically syntaxial quartz overgrowth, is a major cause of porosity-loss in many petroleum reservoirs in moderately to deeply buried sandstones. In the present study, quartz overgrowths appeared to have continued after the chlorite precipitation phase of diagenesis as evidenced by the syntaxial growth of quartz on grains with little or no chlorite coating.

The pore-filling chlorite resulted in a considerable loss of porosity, and the pore-lining chlorite may have helped in retaining the porosity by preventing the precipitation of syntaxial quartz overgrowths, resulting good reservoir quality. There is a negligible positive correlation between chlorite rims and surface porosity (Fig. 9).

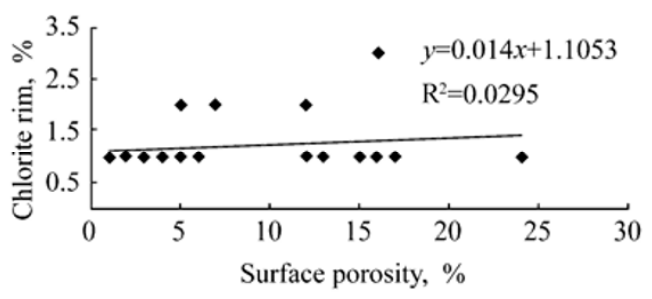

Fig. 9 Core analysis surface porosity vs. the petrographically defined quantity of chlorite

\subsection{Dissolution}

Dissolution in the Tabei sandstones primarily exhibited as dissolution of calcite cements and feldspar. Dissolution improved porosity and permeability of the reservoir. The cause of dissolution was the large amount of organic acid and $\mathrm{CO}_{2}$ generated from maturation of organic matter in the burial history. Dehydration of clay minerals may also accelerate dissolution.

Most of the secondary porosity resulted from the partial to complete dissolution of calcite cement (which will be discussed in details in secondary porosity genesis). Dissolution of detrital feldspar grains also occured. Because the content of feldspar was low and most of the solutions porosity generated in feldspar were inside of the feldspar grain, the effects of feldspar dissolution did not improve reservoir quality much. Dissolution prominently improved reservoir properties, especially in a formation between depths from 4500 to $6300 \mathrm{~m}$. Most of secondary porosity formations were developed at those depths. Porosity created through dissolution ranged from $1 \%$ to $10 \%$ in the Silurian sandstones in the Tabei area. 


\section{Diagenetic stages}

The sequence of diagenetic processes in the sandstones is presented in Fig.10. Due to the complex paragenetic relationships among the authigenic constituents and to the limitation of geothermometric and geochronologic data, only a schematic representation of the diagenetic evolution could be presented.

Based on the distribution and generation orders, variation of vitrinite reflectance, inclusion enclave temperature and mixed layer mineral facies, the sand reservoir in the Tabei area experienced stage A and stage B early diagenesis. At present, it is experiencing stage A of middle diagenesis.

Many clay minerals were generated in stage A of middle diagenesis, such as: kaolinite, illite, chlorite and mixed-layer illite-smectite. Quartz secondary enlargement is of II degree, the palaeogeothermal degree was between $85{ }^{\circ} \mathrm{C}$ and $140{ }^{\circ} \mathrm{C}$ and vitrinite reflectance was between $0.5 \%-1.3 \%$.The organic matter was mature and the rock was consolidated. The diagenesis included dissolution of feldspar, cementation of carbonate, quartz overgrowth, and cementation of illite and chlorite.

On one hand, the $\mathrm{CO}_{2}$ and organic acids generated from maturation and oxidation of organic matter, in addition to meteoric waters, were likely responsible for calcite and feldspar dissolution, so significant secondary porosity was created. On the other hand, the clay minerals drained away intermediary water rapidly and formed ordered mixed-layer minerals. The ordered mixed layers occupied $15 \%-35 \%$ of the clay minerals. The ratio of the minerals of the smectite was $15 \%-50 \%$. The Tabei area is in this stage of sandstone diagenesis.

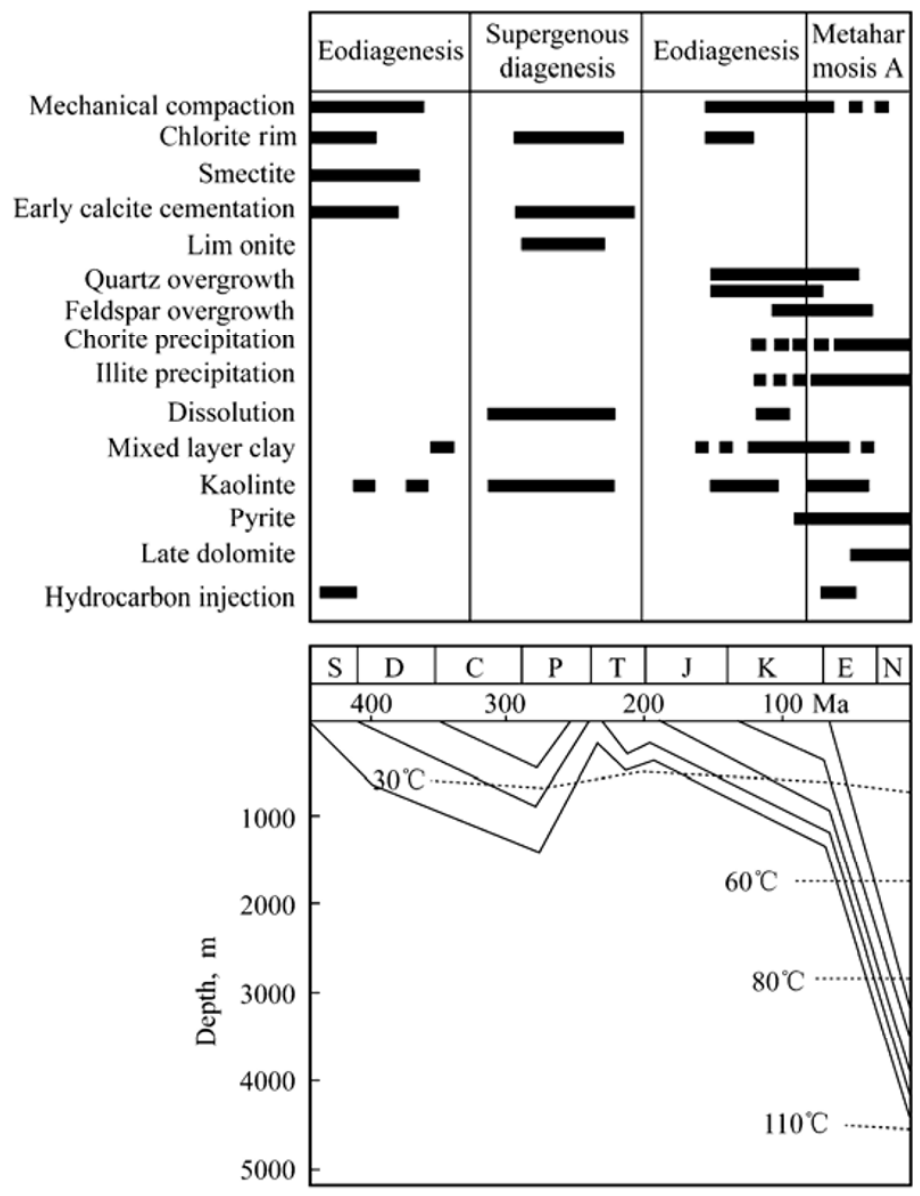

Fig. 10 Diagrams of the paragenetic sequence and history of the Silurian sandstones in the Tabei area, Tarim Basin

\section{Types of pores in sandstones}

The porosity values of the Tabei sandstones range from $1 \%$ to $25 \%$, but are mostly around $9 \%$. Thin section porosity was divided into five categories, including: intergranular pores, intragranular dissolution pores, mold pores, oversized pores (pores larger than normal intergranular pores and comparable to the size of framework grains), micropores and fissures. Of the $9 \%$ average pore space in thin-section, $61 \%$ is intergranular pores, $14 \%$ is intragranular pores and $16 \%$ is mold pores (Fig.11). 


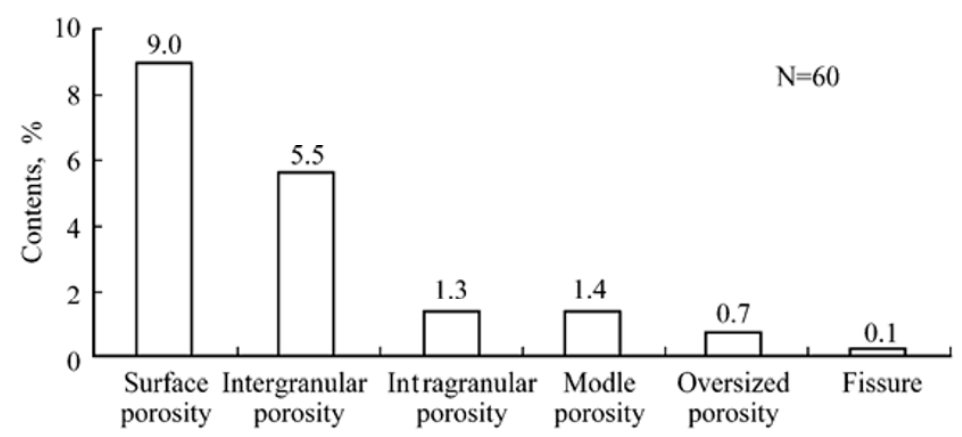

Fig. 11 Types of porosity illustrated by histograms in Silurian reservoir, Tarim Basin

Of the surface porosity (av. $9 \%$; up to $25 \%$ ), $7.7 \%$ are intergranular pores. Intergranular porosity refers to all porosity between grain and grain. It is primary porosity or has resulted from the dissolution of pore-filling cement (Fig.12A) (Felixa, et al., 2005).
Essentially all intergranular pores are thought to be primary porosity in the studied region. Primary pores were mainly those formed during the connate deposition of rocks and have been preserved till now. The primary intergranular pores remain by compaction.
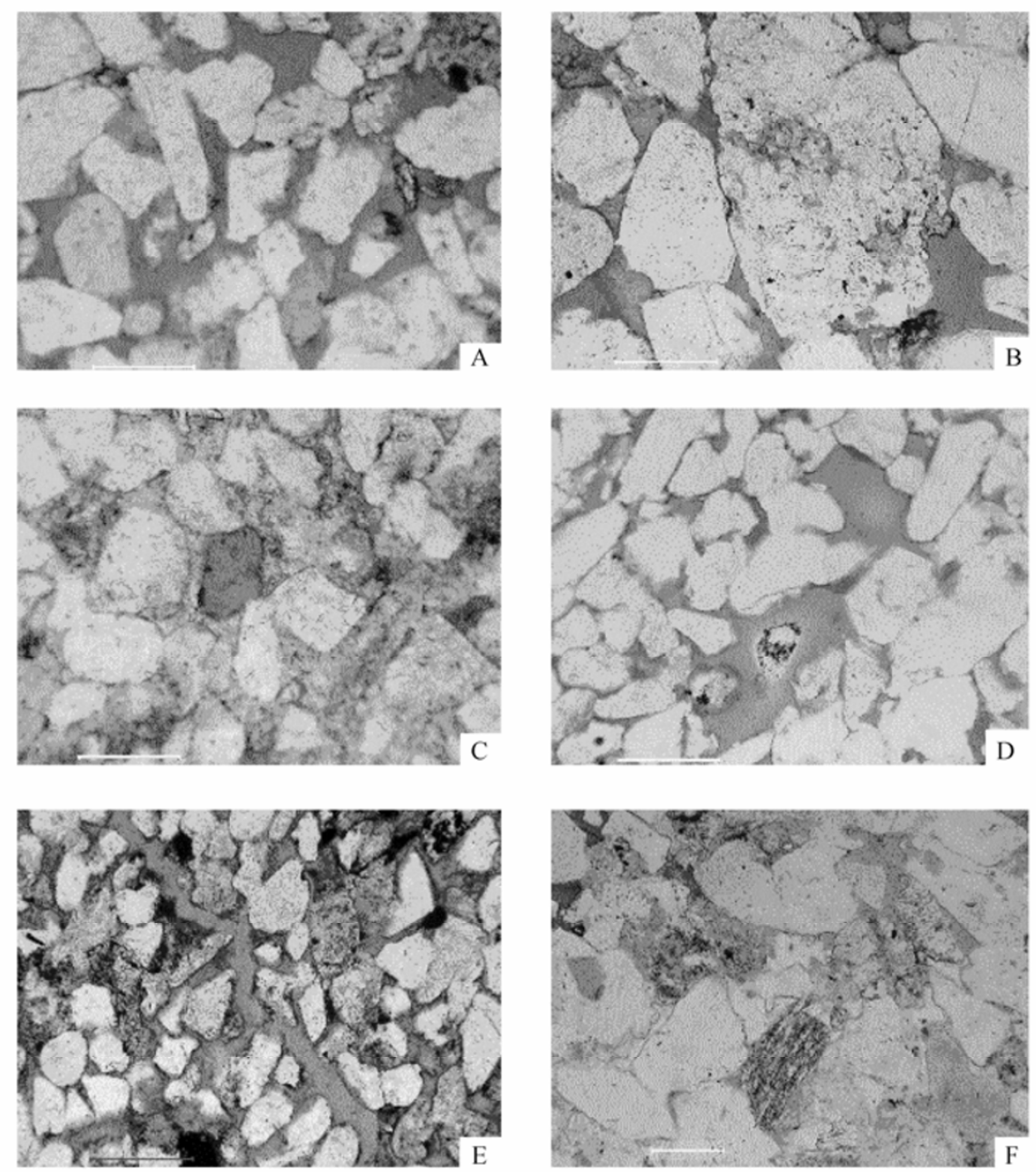

Fig. 12 Optical photomicrographs showing

(A) intergranular pores, Well Ym2(depth 4980.77m); $\quad$ (B) interagranular pores, Well Yw2(depth 5219m); $\quad$ (C) mold pores, Well Yn2(depth 4791m);
(D) oversized pore, Well H1(depth $3738.07 \mathrm{~m}$ );
(E) fissure, Well Ym2 (depth 4742m);
(F) micropores, Well Yw1(depth 5219.2m) 
Intragranular porosity was generally formed by the dissolution of detrital grains (pores within grains) (Fig.12B). Mold pores account $15 \%$ of the surface porosity, they were predominantly generated by the dissolution of detrital feldspar, and sponge spicules (Fig.12C). Oversized pores are intergranular pores and intragranular pores large enough to be identified, it was interpreted as the product of complete detrital grain dissolution (Fig.12D). Fissure porosity is not widespread in the sandstones (Fig.12E), averaging $0.1 \%$. Pore throat size smaller than $0.5 \mu \mathrm{m}$ is defined as microporosity (Fig.12F), which does not contribute significantly to permeability. Microporosity generally generates within altered feldspar grains, ductile grains and authigenic clay aggregates. Microporosity is not only dependent on the amount of rock components but also on the growth habit of the clays.

\section{Origin of secondary pores}

In this study the term 'secondary porosity' refers to the total of intragranular pores plus mold pores and oversized pores. Secondary porosity is mainly associated with the dissolution of mineral cements, whether they are replacing or pore-filling, and is termed cement-dissolution porosity. Most of the porosity in the Tabei sandstones is primary intergranular and little porosity is secondary intergranular and intragranular.

Secondary porosity formed in the Silurian sandstones by the dissolution of calcite cement, partially dissolved feldspars in the Silurian sandstones suggest that oversized pores were formed chiefly by the complete dissolution of feldspar grains (Fig.13). It is possible that a few oversized pores were formed where rock fragments and unstable heavy minerals dissolved also. Calcite cementation played a key role in the porosity evolution of the sandstones. Petrographic evidence indicates that calcite cements were formed early in diagenesis, which were subjected to dissolution, and followed by precipitation of new calcite cements in late diagenesis. The early calcite cementation played a constructive role in porosity preservation because it could prevent significant early mechanical compaction and its dissolution in late diagenesis could generate secondary porosity. Cement dissolution porosity can be created by the dissolution of calcite cement or in the subsurface by pore fluid (meteoric or marine derived formation water) that is undersaturated with respect to carbonates. Although large volumes of meteoric water passed through the sandstones when silica for quartz cement was introduced, calcite cement had not yet precipitated. Thus, the meteoric water that precipitated the quartz cement could not have dissolved the calcite cement. In the final analysis, evidence indicates that some calcite cement has been dissolved from the sandstones recently, but the exact amount is uncertain.
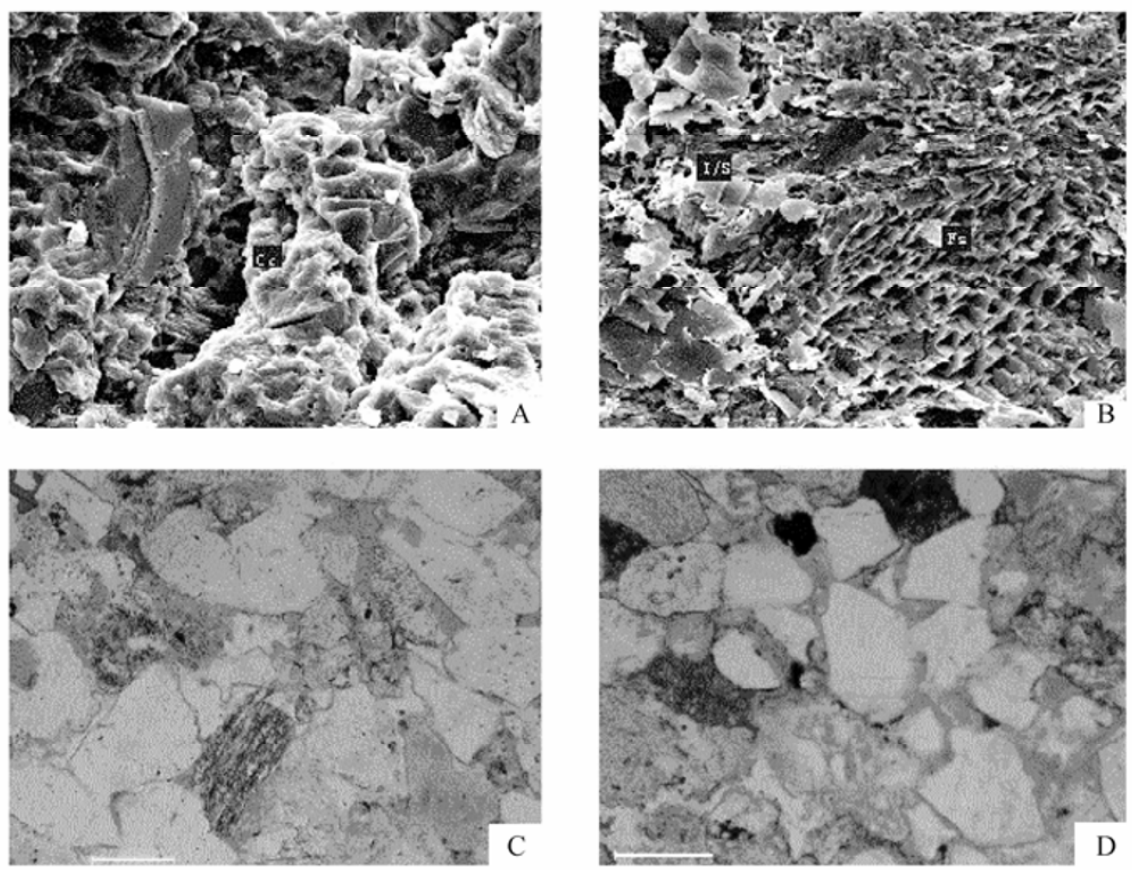

Fig. 13 Thin-section photomicrograph and SEM show secondary porosity of the Tabei sandstone due to partial dissolution of calcite and feldspar, A and B are SEM and C and D are thin-section photomicrograph: (A) Well Th1 (depth 5418.63m); (B) Well H1 (depth 6078.02m); (C) Well Yw1 (depth 5219.20m); (D) Well Yw1 (depth 5246.60m) 
$\mathrm{CO}_{2}$ may not be sufficient to explain the amount of secondary porosity produced by carbonate and feldspar dissolution. On the other hand, carboxylic acids derived from organic matter maturation were efficient agents for dissolution of both carbonates and aluminosilicates. Partially dissolved feldspars in the Tabei sandstones suggest that oversized pores were formed chiefly by the complete dissolution of feldspar grains. It is possible that a few oversized pores were formed where rock fragments and unstable heavy minerals dissolved also.

The other porosity creating process in the Tabei area is leaching. Pristine meteoric waters are undersaturated with carbonates and feldspar, and $\mathrm{H}^{+}$produced through decomposition of vegetation is largely responsible for their leaching capacity. This has affected mainly feldspar. A majority of such feldspar grains have not been totally leached but have rather been replaced by kaolinites and to a certain extent by neomorphic K-feldspars. Considering the amount of the various porosity reducing processes compared to the initial porosity and the present-day porosity, leaching contributed only little deviations of the various porosity reducing processes.

\section{Conclusions}

1) The middle Sk sandstones are litharenite and sublitharenite, the upper $\mathrm{Sk}$ stones are litharenite, sublitharenite and rarely quartz arenite (Well H1), thin-section petrography shows that almost all of the Silurian sandstones are very fine to fine $(0.125-0.25 \mathrm{~mm})$. The shapes of the grains vary from subangular to subrounded. Major types of grain contact are point-line, and the main type of cementation is pore. The types of sorting are different with different formations. The middle Sk, the lower and upper St sandstones are well sorted, but the upper Sk sandstones are middle to well sorted.

2) The diagenetic process recognized includes compaction, cementation, replacement and dissolution. Diagenetic minerals in the Silurian consist of quartz, calcite, dolomite, illite, kaolinite, chlorite, pyrite and feldspar. More porosity was lost by compaction than by cementation in the Tabei reservoirs. The main controls on reservoir quality in Tabei are carbonate cement and total clay minerals.

3) Based on the variation of vitrinite reflectance, inclusion enclave temperature and mixed layer mineral facies, the sandstone reservoirs in the Tabei area experienced stage A and stage B of early diagenesis. At present, it is experiencing stage A of middle diagenesis.

4) Most of the porosity in the Tabei sandstones is primary intergranular and little porosity is secondary intergranular and intragranular. The most commonly observed type of secondary porosity in the Tabei sandstones is dissolution of feldspars. The other porosity creating process in the Tabei area is leaching, but it contributed only little deviations of the various porosity reducing processes

\section{Acknowledgements}

This work was supported by the Ministry of Science and Technology of China and Tarim oilfield Company, PetroChina. Special acknowledgements are due to academician of Chinese Academy of Sciences Liu Baojun for his careful and constructive review, which greatly improved the manuscript. We thank post-doctor Xie Jun for his help in discussion, as well as experimental work of Drs. Si Xunqing, Yang Zicheng and Liu Xiaolin. We gratefully acknowledge analytical facilities for SEM, XRD and thin-section preparation.

\section{References}

Alaa M., Salem S. and Morad S. (2000) Diagenesis and reservoir quality-evolution of fluvial sandstones during progressive burial and uplift: evidence from the Upper Jurassic Boipeba Member, Reconcavo Basin, Northeast Brazil. AAPG Bulletin, 84(7), 1015-1040

Aynur G. B. and Ali S. B. (2005) Clay controls on reservoir properties in sandstone of Kuzgun formation and its relevance to hydrocarbon exploration, Adana basin, Southern Turkey. Journal of Petroleum Science and Engineering, 47, 123-135

Carvalho M. V. F., De Ros L. F. and Gomes N. S. (1995) Carbonate cementation patterns and diagenetic reservoir facies in the Campos Basin Cretaceous turbidites, offshore eastern Brazil. Marine and Petroleum Geology, 12, 741-758

Ehrenberg S. N. (1989) Assessing the relative importance of compaction and cementation to reduction of porosity in sandstones: Discussion; Compaction and porosity evolution of Pliocene sandstones, Ventura Basin, California: Discussion. Bulletin American Association Petroleum Geologists, 73, 1274-1276

Felixa L.C., Luis A. and Munoz B. (2005) Representing a relation between porosity and permeability based on inductive rules. Journal of Petroleum Science and Engineering, 47, 23-34

Fisher Q. J., Casey M. and Clennell M. B. (1999) Mechanical compaction of deeply buried sandstones of the North Sea. Marine and Petroleum Geology, 16, 605-618

Folk R. L. (1968) Petrology of sedimentary rocks. Austin, TX: Hemphill, 107p

Haszeldine R. S. and Macaulay C. I. (2000) Sandstone cementation and fluids in hydrocarbon basins. Journal of Geochemical Exploration, 69-70, 195-200

Hiatt E., Kyserb K. and Dalrymple R. W. (2003) Relationships 
among sedimentology, stratigraphy, and diagenesis in the Proterozoic Thelon Basin, Nunavut, Canada: implications for paleoaquifers and sedimentary-hosted mineral deposits. Journal of Geochemical Exploration, 80, 221-240

Khalid A., Hussain M., Imam B. and Saner S. (2004) Lithologic characteristics and diagenesis of the Devonian Jauf sandstone at Ghawar Field, Eastern Saudi Arabia. Marine and Petroleum Geology, 21, 1221-1234

Madhavaraju J., Ramasamy M., Ruffell A. and Mohan S. P. (2002) Clay mineralogy of the Late Cretaceous and early Tertiary successions of the Cauvery Basin (southeastern India): implications for sediment source and palaeoclimates at the K/T boundary. Cretaceous Research, 23, 153-163

Marfil R., Scherer M. and Turrero M. J. (1996) Diagenetic processes influencing porosity in sandstones from the Triassic Buntsandstein of the Iberian Range, Spain. Sedimentary Geology, 105, 203-219

Pimentel N. L. (2002) Pedogenic and early diagenetic processes in Palaeogene alluvial fan and lacustrine deposits from the Sado Basin (S Portugal). Sedimentary Geology, 148, 123-138

Schmid S., Worden R. H. and Fisher Q. J. (2004) Diagenesis and reservoir quality of the Sherwood Sandstone (Triassic), Corrib Field, Slyne Basin, west of Ireland. Marine and Petroleum Geology, 21, 299-315

Wescott W. A. (1983) Diagenesis of Cotton Valley sandstone (Upper Jurassic), East Texas: Implication for tight gas form action pay recognition. AAPG Bulletin, 67(6), 1002-1013
Worden R. H. and Morad S. (2000) Quartz cementation in oil field sandstones: A review of the key controversies. In R. H. Worden, \& S. Morad, Quartz cementation in sandstones. Oxford: Blackwell, Special Publications of the Iinternational Association of Sedimentologists, Vol.29, 1-20

Zhang J. L. (2004) Diagenesis of lacustrine deltaic sandstone and its impact on reservoir quality, Acta Sedimentologica Sinica, 22(2), 225-233 (in Chinese).

Zhang J. L. and Shen F. (1990) Clastic diagenesis and reservoir properties of the third member of Shahejie formation, Qiaokou area, Dongqu Depression. Minerals and Rocks, 10(1), 35-42 (in Chinese)

\section{About the first author}

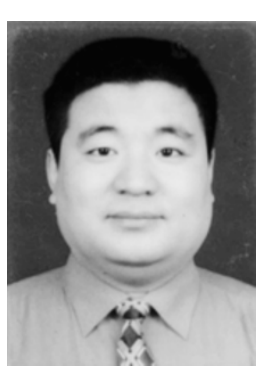

Zhang Jinliang, born in 1962, received his $\mathrm{PhD}$ degree at the Chengdu University of Technology in 1990. Now he is a professor in the Ocean University of China. His major research interests cover sedimentary geology, reservoir geology, sequence stratigraphy and analysis of petroliferous basin. E-mail: jinliang@ouc.edu.cn

(Received June 15, 2006) (Edited by Yang Lei) 